\title{
PENCEMARAN PLASTIK DI LAUT
}

\author{
Oleh \\ M. Reza Cordova ${ }^{1)}$
}

\begin{abstract}
PLASTICS POLLUTION IN THE SEA. Indonesia is considered as the second biggest plastic waste producer in the sea. Information on waste pollution and its impact on marine organisms in Indonesia is still limited. Waste disposal and solid waste (plastics) into the sea are continuously occuring; elevating the thoughts of global impact of plastic waste contamination. Increased use of plastic is a consequence of the development of technologies, industries and also the population. This paper is expected to provide knowledge and information of plastics that exist in the sea, especially Indonesian Sea.
\end{abstract}

\section{PENDAHULUAN}

Kawasan pesisir dan laut merupakan lingkungan perairan yang mudah terpengaruh dengan adanya buangan limbah dari darat. Bahan pencemar yang berasal dari berbagai kegiatan industri, pertanian, rumah tangga di daratan akhirnya menimbulkan dampak negatif bukan saja pada sungai, tetapi juga pesisir dan lautan. Dampak yang terjadi antara lain kerusakan ekosistem mangrove, padang lamun, terumbu karang, kehidupan dari jenis-jenis biota laut yang hidup di dalamnya, dan abrasi (UNEP, 2011). Salah satu bahan pencemar yang berdampak negatif pada biota laut adalah pembuangan sampah plastik.

Plastik hadir dalam setiap aspek kehidupan kita sehari-hari, karena sifat plastik yang menguntungkan (serbaguna, ringan, kuat, tahan lama dan murah). Plastik digunakan dalam berbagai aplikasi, mulai dari rumah tangga dan barangbarang pribadi, pakaian dan kemasan untuk bahan bangunan dan transportasi (Santos \& Duarte, 2015). Sampah plastik merupakan masalah besar, bukan hanya di Indonesia, tetapi di seluruh dunia. Menurut Kemenperin (2013), sekitar 1,9 juta ton plastik diproduksi selama tahun 2013 di Indonesia, dengan rata-rata produksi 1,65 juta ton/tahun. Thompson et al. (2009) memperkirakan bahwa 10\% dari semua plastik yang baru diproduksi akan dibuang melalui sungai dan berakhir di laut. Hal ini berarti sekitar 165 ribu ton plastik/tahun akan bermuara ke perairan laut Indonesia.

Peningkatan penggunaan plastik ini merupakan konsekuensi dari berkembangnya teknologi, industri dan juga jumlah populasi penduduk. Di Indonesia, kebutuhan plastik terus meningkat hingga mengalami kenaikan rata-rata 200 ton per tahun. Tahun 2002, tercatat 1,9 juta ton, tahun 2003 naik menjadi 2,1 juta ton, selanjutnya tahun 2004 naik lagi menjadi 2,3 juta ton per tahun. Pada ta-

\footnotetext{
1) Kelompok Penelitian Pencemaran Laut dan Bioremediasi, Pusat Penelitian Oseanografi-LIPI, Jakarta
} 
hun 2010, kebutuhan plastik sekitar 2,4 juta ton, dan pada tahun 2011 meningkat menjadi 2,6 juta ton. Akibat dari peningkatan penggunaan plastik tersebut, maka dampaknya adalah bertambah pula sampah plastik (Surono, 2013). Berdasarkan asumsi Kementerian Lingkungan Hidup (KLH), setiap hari penduduk Indonesia menghasilkan $0,8 \mathrm{~kg}$ sampah per orang atau secara total sebanyak 189 ribu ton sampah/hari. Dari jumlah tersebut, $15 \%$ berupa sampah plastik atau sejumlah 28,4 ribu ton sampah plastik/ hari. Pencemaran laut yang disebabkan oleh sampah plastik yang ada di perairan Indonesia harus segera ditangani secara holistik dan berkelanjutan dengan penuh kesadaran akan perlindungan dan pengelolaan lingkungan perairan Indonesia. Tulisan ini diharapkan memberikan pengetahuan dan informasi pencemaran plastik yang ada di laut, khususnya Indonesia.

\section{PLASTIK}

Plastik merupakan jenis makromolekul yang dibentuk dengan proses polimerisasi, yaitu proses penggabungan beberapa molekul sederhana (monomer), melalui proses kimia menjadi molekul besar (makromolekul atau polimer). Untuk membuat plastik, salah satu bahan baku yang sering digunakan adalah naphta, yaitu bahan yang dihasilkan dari penyulingan minyak bumi atau gas alam (PlasticsEurope, 2013).

Plastik dapat dikelompokkan menjadi dua macam yaitu thermoplastic dan termosetting. Thermoplastic adalah bahan plastik yang jika dipanaskan sampai suhu tertentu, akan mencair dan dapat dibentuk kembali menjadi bentuk yang diinginkan. Adapun thermosetting adalah plastik yang jika telah dibuat dalam bentuk padat, tidak dapat dicairkan kembali dengan cara dipanaskan. Berdasarkan sifat kedua kelompok plastik di atas, termoplastik termasuk jenis yang memungkinkan untuk didaur ulang (Surono, 2013). Jenis termoplastik yang dapat didaur ulang diberi kode berupa nomor untuk memudahkan dalam mengidentifikasi dan penggunaannya (Gambar 1; Tabel 1). Daya tahan dan persistensi dari plastik, dikombinasikan dengan meningkatnya produksi dan rendahnya tingkat pemulihan (US EPA, 2014).

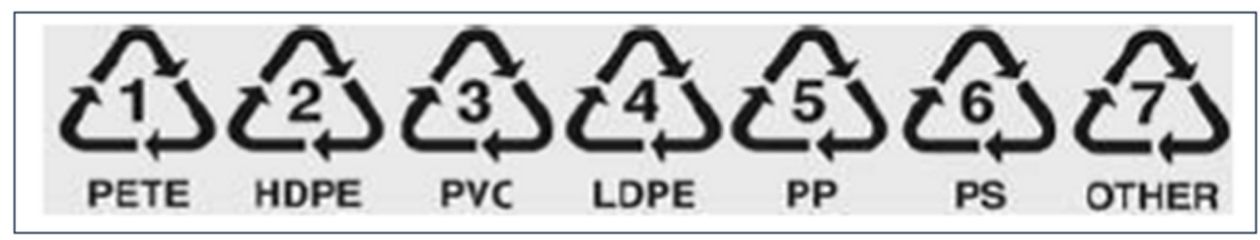

Gambar 1. Nomor kode plastik

(UNEP, 2009) 
Tabel 1. Jenis plastik, kode dan penggunaannya

\begin{tabular}{|c|l|l|}
\hline $\begin{array}{c}\text { No. } \\
\text { Kode }\end{array}$ & Jenis Plastik & Penggunaan \\
\hline 1 & $\begin{array}{l}\text { PETE (polyethylene } \\
\text { terephthalate) }\end{array}$ & $\begin{array}{l}\text { botol kemasan air mineral, botol minyak goreng, } \\
\text { jus, botol sambal, botol obat, dan botol kosmetik }\end{array}$ \\
\hline 2 & $\begin{array}{l}\text { HDPE (High-density } \\
\text { Polyethylene) }\end{array}$ & $\begin{array}{l}\text { botol obat, botol susu cair, jerigen pelumas, dan } \\
\text { botol kosmetik }\end{array}$ \\
\hline 3 & $\begin{array}{l}\text { PVC (Polyvinyl Chlo- } \\
\text { ride) }\end{array}$ & $\begin{array}{l}\text { pipa selang air, pipa bangunan, mainan, taplak } \\
\text { meja plastik, botol shampo dan botol sambal }\end{array}$ \\
\hline 4 & $\begin{array}{l}\text { LDPE (Low-density } \\
\text { Polyethylene) }\end{array}$ & $\begin{array}{l}\text { kantong kresek, tutup plastik, plastik pem- } \\
\text { bungkus daging beku, dan berbagai macam plastik } \\
\text { tipis lainnya. }\end{array}$ \\
\hline 5 & $\begin{array}{l}\text { PP (Polypropylene } \\
\text { atau Poly-propene) }\end{array}$ & $\begin{array}{l}\text { cup plastik, tutupbotol dari plastik, mainan anak, } \\
\text { dan margarine }\end{array}$ \\
\hline 6 & $\begin{array}{l}\text { PS (Polystyrene) } \\
\text { kotak CD, sendok dan garpu plastik, gelas plastik } \\
\text { atau tempat makanan dari styrofoam, dan terupat } \\
\text { makan plastik transparan }\end{array}$ \\
\hline 7 & $\begin{array}{l}\text { Other (0), jenis plastik } \\
\text { lainnya selain no 1 - } 6\end{array}$ & $\begin{array}{l}\text { botol susu bayi, plastik kemasan, gallon air mi- } \\
\text { num, suku cadang mobil, alat-alat rumah tangga, } \\
\text { komputer, alat-alat elektronik, sikat gigi dan main- } \\
\text { an lego }\end{array}$ \\
\hline
\end{tabular}

Sumber: Kurniawan (2012)

\section{PENCEMARAN PLASTIK DAN DAMPAKNYA PADA KEHIDUPAN DI LAUT}

Pencemaran laut adalah masuknya atau dimasukkannya makhluk hidup, zat, energi, dan/atau komponen lain ke dalam lingkungan laut oleh kegiatan manusia, sehingga kuantitasnya turun sampai ke tingkat tertentu yang menyebabkan lingkungan laut tidak sesuai lagi dengan baku mutu dan/atau fungsinya (PP-RI 19/1999). Bahan pencemar termasuk partikel kimia, limbah industri, limbah pertanian dan perumahan, yang masuk ke dalam laut memiliki dampak yang bermacam-macam. Sampah plastik yang dibuang, terapung dan akan terendap di lautan. Massa plastik di lautan diperkirakan menumpuk hingga seratus juta metrik ton. Kondisi ini sangat berpengaruh buruk, dan sangat sulit terurai oleh bakteri. Sumber sampah plastik di laut juga berasal dari jaring ikan yang sengaja dibuang atau tertinggal di dasar laut

Menurut NOAA (2013,) sampah laut (marine debris) ialah benda padat yang kuat dan tahan lama, diproduksi atau diproses oleh manusia, secara langsung 
atau tidak langsung, sengaja atau tidak sengaja, dibuang atau ditinggalkan di dalam lingkungan laut. Tipe sampah laut di antaranya plastik, kain, busa, styrofoam (gabus), kaca, keramik, logam, kertas, karet, dan kayu. Sampah plastik merupakan salah satu jenis plastik yang mencemari laut. Penggunaan plastik dalam berbagai kegiatan manusia menyebabkan produksi plastik semakin meningkat. Andrady (2011) menyatakan lebih dari dua ratus juta ton plastik telah diproduksi sejak pertengahan abad terakhir. Produksi global polimer organik sintetik, yang disebut "plastik" telah meningkat dari sekitar 0,5 juta ton per tahun pada tahun 1950 sampai dengan 288 juta ton pada tahun 2012 (PlasticsEurope, 2013). Sekitar 10\% dari seluruh plastik, menjadi sampah di lautan dunia melalui pembuangan yang disengaja dan penanganan yang tidak tepat (Wright et al., 2013).
Konsumsi berlebih terhadap plastik, mengakibatkan jumlah sampah plastik yang besar. Plastik sintesis merupakan 90\% dari total produksi dunia (Andrady \& Neal, 2009). Polyethylene (PE), polypropylene (PP), polyvinyl chloride (PVC), polystyrene (PS) dan polyethylene terephthalate (PET) yang memiliki densitas rendah dan tinggi, merupakan plastik sintetis yang paling banyak digunakan dan menjadi polutan di lingkungan pesisir dan laut (Andrady, 2011; Engler, 2012). Plastik sintesis bukan berasal dari senyawa biologis, dan memiliki sifat yang sulit terdegradasi (non biodegradable). Plastik diperkirakan membutuhkan waktu 100 sampai 500 tahun, hingga dapat terdekomposisi (terurai) dengan sempurna.

Plastik merupakan tipe sampah laut yang dominan (CBD-STAP, 2012). Polusi plastik telah ditemukan dalam habitat laut dari kutub ke khatulistiwa dan dari garis pantai ke laut dalam (Browne et al., 2011). Penelitian terbaru mendokumen-

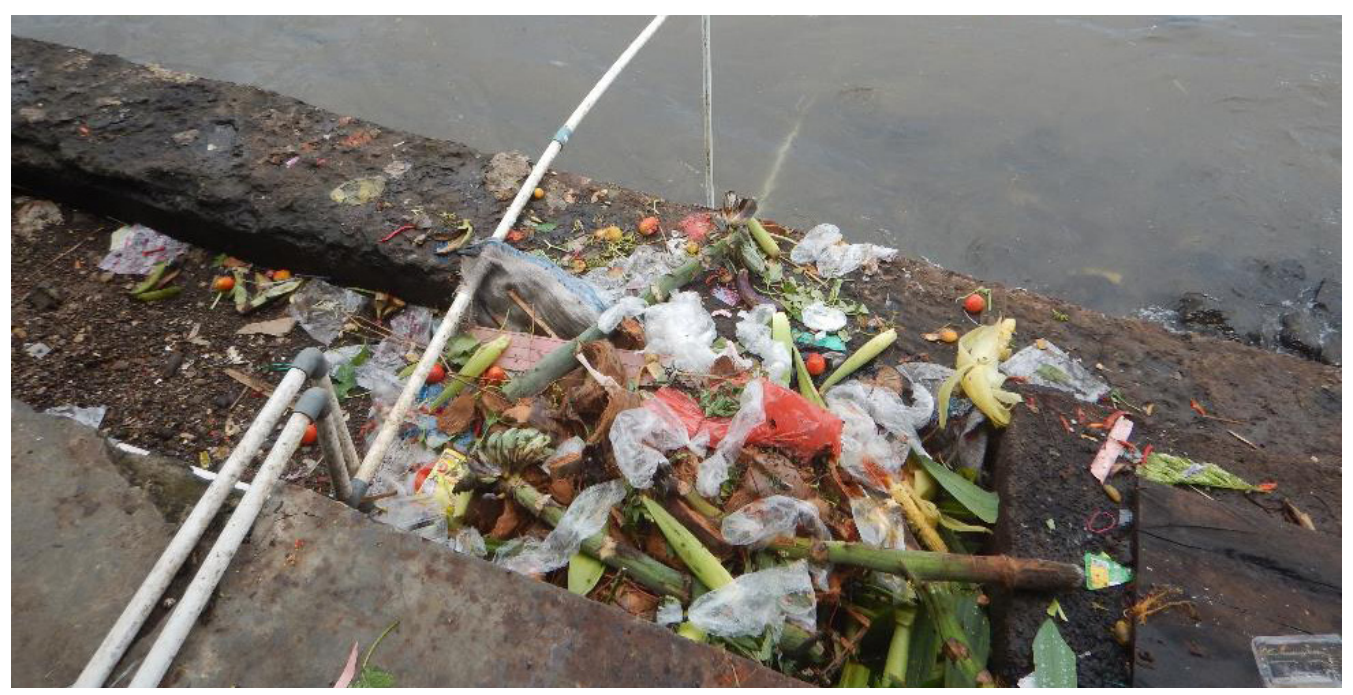

Gambar 2. Pembuangan sampah yang disengaja ke ekosistem perairan laut (Sumber: Dokumentasi pribadi di perairan pantai Ternate, 2017). 
tasikan peningkatan sampah di Samudera Pasifik (Eriksen et al., 2013; Goldstein, 2012). Sampah plastik yang bervariasi diklasifikasikan menurut ukuran, asal, bentuk, dan komposisi. Kategori ukuran digunakan untuk mengklasifikasikan marine debris, yaitu mega plastik debris ( $>$ $100 \mathrm{~mm}$ ), makro plastik debris (> 20-100 $\mathrm{mm})$, meso plastik debris $(>5-20 \mathrm{~mm})$, dan mikro plastik debris $(0.3-5 \mathrm{~mm})$. Sampah plastik menunjukkan berbagai bentuk, selain benda-benda plastik dikenali, bentuk yang paling umum adalah potongan (fragmen), film, pelet, garis, serat, filamen, dan butiran (Andrady, 2011).

Sampah plastik dapat memiliki dampak ekologi dan ekonomi yang luas di perairan tawar dan lingkungan laut. Dampak negatif langsung dari perkembangan jumlah plastik yang sangat banyak pada organisme laut, seperti terjerat oleh plastik dan membuat penyumbatan pada saluran pencernaan (Gambar 2) (Gregory, 2009). Sekitar 370 spesies hewan laut telah ditemukan terjerat dalam atau telah menelan sampah laut di seluruh dunia (CBD, 2012; Galgani et al., 2013). Tujuh spesies penyu laut, 14 spesies cetacean, 20 spesies anjing laut, dan 56 spesies burung laut ditemukan terjerat dan mengkonsumsi plastik dalam jumlah besar dan mengakumulasi bahan kimia yang menempel di plastik (Katsanevakis, 2008, Tanaka et al., 2013; Acampora et al., 2014).

Sampah plastik ukuran besar, megaplastik dan makroplastik, menimbulkan resiko kesehatan secara langsung bagi hewan air, termasuk ikan, penyu, burung, serta penyu laut, karena salah konsumsi (Boerger et al., 2010). Konsumsi plastik oleh hewan air dapat menyebabkan pendarahan internal dan bisul, serta penyumbatan pada saluran pencernaan (Wright et al., 2013). Efek negatif dari plastik juga dapat memberikan dampak lain seperti terikatnya invertebrata bentik, burung, ikan, mamalia dan penyu oleh kabel plastik dan jaring

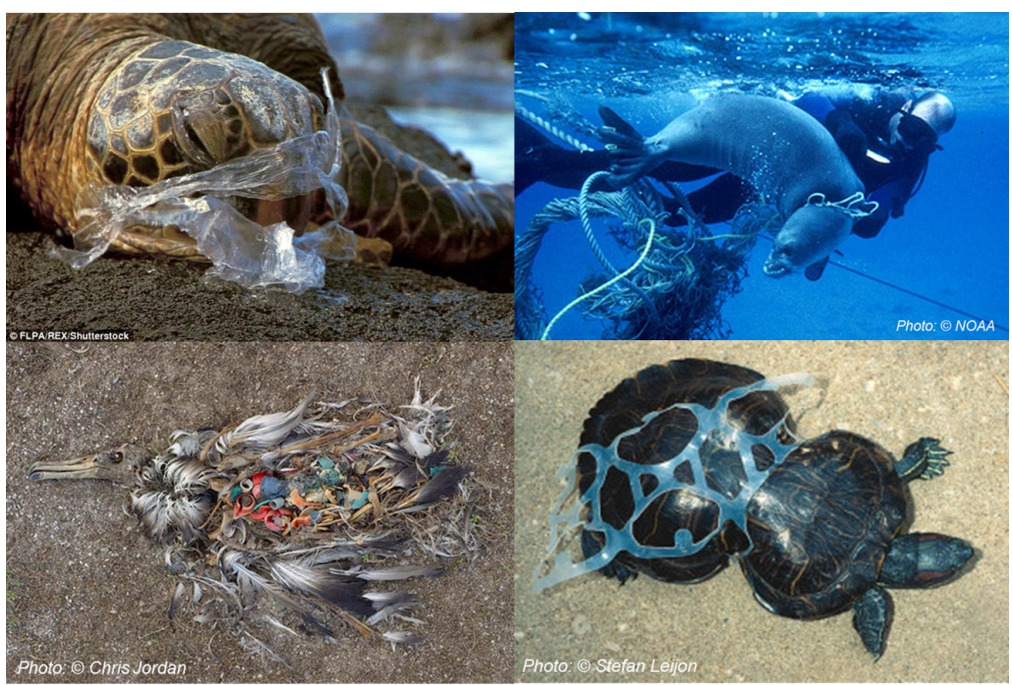

Gambar 3. Dampak langsung sampah plastik pada biota (plastic-pollution.org) 
(Besseling et al., 2013; Wegner et al., 2012; Foekema et al., 2013). Sampah plastik dapat bertindak sebagai vektor untuk kontaminan, termasuk polutan organik persisten (POPs), polychlorinated biphenyls (PCB), hidrokarbon aromatik polisiklik (PAH), dichlorodiphenyltrichloroethane (DDT), difenileter bifenil (PBDE), dan bisphenol A (BPA) dan logam berat (Ashton et al., 2010; Holmes et al., 2012; Zarfl \& Matthies, 2010). Hal tersebut menunjukkan pentingnya meneliti plastik sebagai media transportasi polutan dari lingkungan perairan ke biota laut dan manusia (Tanaka et al., 2013), karena plastik memiliki dampak yang signifikan terhadap organisme laut (Murray \& Cowie, 2011; Van Franeker et al., 2011; von Moos et al., 2012; Fossi et al., 2012; Farrell \& Nelson, 2013; Cole et al., 2013).

Potensi efek secara kimia cenderung meningkat seiring menurunnya ukuran partikel plastik (mikroplastik), sedangkan efek secara fisik meningkat seiring meningkatnya ukuran makrodebris (UNEP, 2011). Bila makrodebris memberikan dampak secara fisik, seperti me- nutup permukaan sedimen dan mencegah pertumbuhan benih mangrove (Smith, 2012), maka kehadiran mikroplastik dalam sedimen pesisir mengakibatkan konsekuensi yang tak terduga, seperti perubahan sifat secara fisik dari pantai dan masalah yang terkait lainnya (Carson et al, 2011). Semakin kecil partikel, semakin besar kemungkinan plastik untuk dicerna oleh kehidupan di laut (Carson, 2013; von Moos et al., 2012; Andrady, 2011).

Plastik dengan ukuran kurang dari $5 \mathrm{~mm}$ yang disebut mikroplastik, terlihat seperti organisme planktonik dan partikel organik tersuspensi, yang merupakan makanan bagi biota laut (Wright et al., 2013). Mikroplastik akan memberikan dampak negatif dari plastik bagi biota laut. Ukurannya yang mikroskopis membuat kemungkinan bioavailability dari mikroplastik terjadi melalui saluran pencernaan (Betts, 2008). Biota laut yang terdeteksi mengakumulasi mikroplastik diantaranya adalah kopepoda dan kepiting (Cole et al., 2013, Farrell \& Nelson, 2013), kima

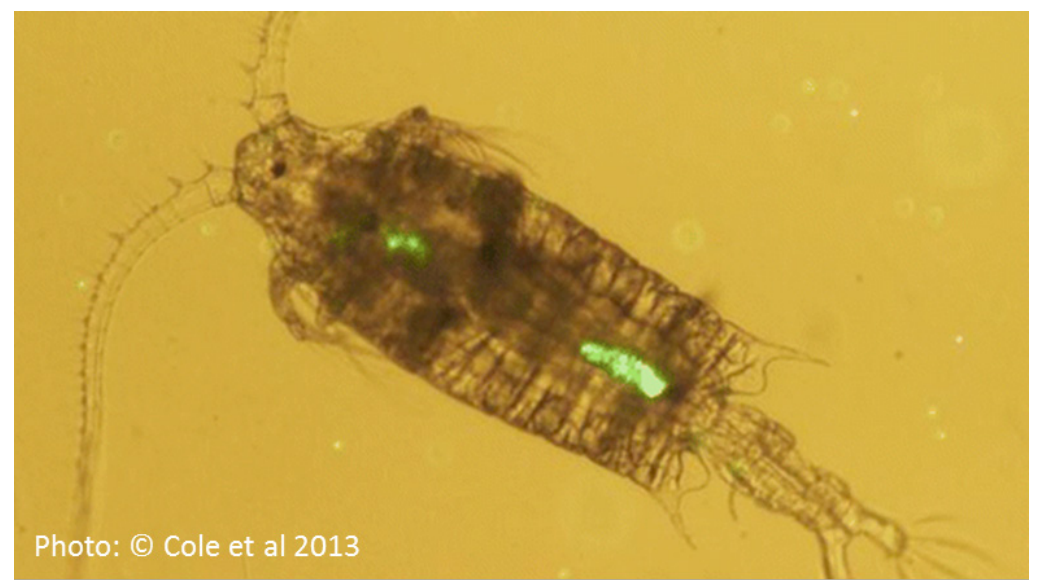

Gambar 4. Plastik ukuran mikroskopis yang dimakan plankton (Cole et al., 2013) 
(Van Cauwenberghe \& Janssen, 2014), dan kerang biru. Dampak langsung mikroplastik yang masuk ke tubuh organisme laut tersebut mengganggu kerja saluran pencernaan (Cole et al., 2013) dan sebagai vektor/pembawa bahan tambahan, dan juga bahan pencemar organik lain yang teradsorpsi pada mikroplastik (Teuten et al., 2009).

\section{PENUTUP}

Penggunaan plastik dalam berbagai kegiatan manusia menyebabkan produksi plastik semakin meningkat. Polusi plastik awalnya dilihat hanya masalah estetika, tetapi penelitian selama beberapa dekade terakhir menunjukkan bahwa biota laut dapat terkena dampak negatif seperti salah konsumsi, lilitan, dan tersangkut/terjerat. Plastik yang masuk ke ekosistem laut mengalami degradasi baik secara oksidasi termal dengan radiasi ultraviolet, dan degradasi secara mekanik sehingga ukurannya akan semakin kecil. Semakin kecil ukuran dari plastik akan meningkatkan kemungkinan bioavailabilitas plastik pada organisme laut. Dampak langsung plastik pada biota laut seperti terjerat dan salah konsumsi yang menyebabkan penyumbatan pada saluran pencernaan. Dampak tidak langsung akibat pencemaran plastik dapat berupa menempelnya bahan pencemar pada plastik dan terkonsumsi oleh biota. Dengan alasan tersebut, diperlukan penelitian untuk mengetahui seberapa besar potensi pencemaran yang terjadi akibat sampah plastik pada kawasan ekosistem laut di Indonesia, sehingga diperoleh data yang baik untuk pengelolaan sampah plastik yang tepat.

\section{REFERENSI}

Acampora, H., Q.A Schuyler, K.A. Townsend, and B.D. Hardesty. 2014. Comparing Plastic Ingestion in Juvenile and Adult Stranded Short-Tailed Shearwaters (Puffinus Tenuirostris) in Eastern Australia. Marine Pollution Bulletin 78 (1): 63-68.

Andrady, A.L. 2011. Microplastics in the Marine Environment. Mar. Poll. Bull. 62: 1596-1605.

Ashton, K., L. Holmes and A. Turner. 2010. Association of Metals With Plastic Production Pellets in the Marine Environment. Mar. Poll. Bul. 60: 2050- 2055.

Besseling, E., A. Wegner, E.M. Foekema, M. van den Heuvel-Greve and A.A. Koelmans. 2013. Effects of Microplastic on Fitness and PCB Bioaccumulation by The Lugworm Arenicola marina (L.). Environmental Science and Technology 47: 593-600.

Betts, K. 2008. Why Small Plastic Particles May Pose A Big Problem in the Oceans. Env. Sci. and Tech. 42 (24): 8995-8995.

Boerger, C.M., G.L. Lattin, S.L. Moore and C.J. Moore. 2010. Plastic Ingestion By Planktivorous Fishes in The North Pacific Central Gyre. Mar. Poll. Bull. 60 (12): 2275-2278.

Browne, M.A., P. Crump, S.J. Niven, E. Teuten, A. Tonkin, T. Galloway and R.C.Thompson. 2011. Ac- 
cumulation of Microplastic on Shorelines Worldwide: Sources and Sinks. Env. Sci. and Tech. 45: 9175-9179.

Carson, H.S., S.L. Colbert, M.J. Kaylor and K.J. McDermid. 2011. Small Plastic Debris Changes Water Movement and Heat Transfer Through Beach Sediments. Mar. Poll. Bull. 62: 1708-1713.

Carson, H.S., M.S. Nerheim, K.A. Carroll and M. Eriksen. 2013. The Plastic-Associated Microorganisms of the North Pacific gyre. Mar. Poll. Bul. 75: 126 -132.

[CBD] Convention on Biological Diversity. 2012. Impacts of Marine Debris on Biodiversity: Current Status and Potential Solutions. Secretariat of the Convention on Biological Diversity and the Scientific and Technical Advisory Panel GEF. Technical Series No. 67, Montreal: 61 hlm.

Cole, M., P. Lindeque, E. Fileman, C. Halsband, R.M. Goodhead, J. Moger and T. Galloway. 2013. Microplastic Ingestion By Zooplankton. Environmental Science and Technology 47: 6646- 6655. http://dx.doi. org/10.1021/es400663f.

Engler, R.E. 2012. The Complex Interaction Between Marine Debris and Toxic Chemicals In The Ocean. Environmental Science and Technology 46 (22): 12302-12315.
Eriksen, M., N. Maximenko, M. Thiel, A. Cummins, G. Lattin, S. Wilson and S. Rifman. 2013. Plastic Pollution in The South Pacific Subtropical Gyre. Mar. Poll. Bull. 68 (1): 71-76.

Farrell, P. and K. Nelson. 2013. Trophic Level Transfer of Microplastics: Mytilus Edulis (L.) To Carcinus Maenas (L.). Environmental Pollution 177: 1-3.

Foekema, E.M., C. De Gruijter, M.T. Mergia, J.A. van Franeker, A.J Murk and A.A. Koelmans. 2013. Plastic in North Sea fish. Environ. Sci. Technol. 47, 8818-8824. http://dx.doi. org/10.1021/es400931.

Fossi, M.C., C. Panti, C. Guerranti, D. Coppola, M. Giannetti, L. Marsili and R. Minutoli. 2012. Are Baleen Whales Exposed to The Threat of Microplastics? A Case Study of The Mediterranean Fin Whale (Balaenoptera physalus). Mar. Poll. Bull. 64: 2374-2379. http:// dx.doi.org/10.1016/j.marpolbul.2012.08.013.

Galgani, F., G. Hanke, S. Werner and L. De Vrees. 2013. Marine Litter Within The European Marine Strategy Framework Directive. ICES Journal of Marine Science 70 (6): 1055-1064.

Goldstein, M.C., M. Rosenberg and L. Cheng. 2012. Increased Oceanic Microplastic Debris Enhances Oviposition in An Endemic 
Pelagic Insect. Biology Letters 8 (5): 817-820.

Gregory, M.R. 2009. Environmental Implications of Plastic Debris In Marine Settings - Entanglement, Ingestion, Smothering, Hangers-On, Hitch-Hiking And Alien Invasions. Philos. Trans. Roy. Soc. B: Biol. Sci. 364 (1526): 2013-2025.

Holmes, L. A. 2013. Interactions of trace metals with plastic production pellets in the marine environment [thesis]. Plymouth (UK): University of Plymouth.

Katsanevakis, S. 2008. Marine Debris, A Growing Problem: Sources, Distribution, Composition, and Impacts. New Research. Nova Science Publishers, New York, Marine Pollution, 53-100.

Kementerian Perindustrian dan Perdagangan. 2013. Konsumsi plastik 1,9 juta ton [Internet]. http://www.kemenperin.go.id/ artikel/6262/Semester-I,-Konsumsi-Plastik-1,9-Juta-Ton. Diakses pada tanggal 1 April 2015

Murray, F. and P.R Cowie. 2011. Plastic Contamination In The Decapod Crustacean Nephrops norvegicus (Linnaeus, 1758). Marine Pollution Bulletin 62, 1207-1217. http:// dx.doi.org/10.1016/j.marpolbul.2011.03.032.

Mohamed Nor, N.H. and J.P. Obbard. 2014. Microplastics in Singa- pore's Coastal Mangrove Ecosystems. Mar. Poll. Bull. 79 (1): 278-283.

National Oceanic and Atmospheric Administration. 2013. Programmatic Environmental Assessment (PEA) for the NOAA Marine Debris Program (MDP). Maryland (US): NOAA. 168 p.

[PP-RI] Peraturan Pemerintah No. 19 Tahun 1999 Tentang : Pengendalian Pencemaran Dan/Atau Perusakan Laut

Plastics Europe. 2013. Plastics the Facts 2013. An Analysis of European Latest Plastics Production, Demand and Waste Data. Plastics Europe: Association of Plastic Manufacturers, Brussels, p. 40.

Santos, T.R. and A.C. Duarte. 2015. A Critical Overview of The Analytical Approaches to The Occurrence, The Fate and the Behavior of Microplastics in the Environment. Trends in Analytical Chemistry 65 (2015): 47-53.

Smith, S.D.A. 2012. Marine debris: A proximate threat to marine sustainability in Bootless Bay, Papua New Guinea. Mar. Poll. Bull. 64:1880- 1883. do i : $10.1016 / \mathrm{j}$. marpolbul.2012.06.013.

Surono, U. B. 2013. Berbagai Metode Konversi Sampah Plastik Menjadi Bahan Bakar Minyak. 
Jurusan Teknik Mesin Universitas Janabadra Yogyakarta

Tanaka, K., H. Takada, R. Yamashita, K. Mizukawa, M. Fukuwaka and Y. Watanuki. 2013. Accumulation of Plastic-Derived Chemicals in Tissues Of Seabirds Ingesting Marine Plastics. Mar. Poll. Bul. 69, 219-222.

Teuten, E.J. J.M. Saquing, D.R.U. Knappe, M.A. Barlaz, S. Jonsson, A Bjorn, S.J. Rowlamd, R.C. Thompson, T.S. Galloway, R. Yamashita, D. Ochi, Y. Watanuki, C. Moore, P.H. Viet, T.S. Tana, M. Prudente, R. Boonyatumanond, M.P. Zakaria, K. Akkhavong, Y. Ogata, H. Hirai, S. Isawa, K. Mizukawa, Y. Hagino, A. Imamura, M. Saha and H. Takada, , 2009. Transport And Release Of Chemical From Plastics To The Environment and To Wildlife. Philos. Trans. R. Soc. B. 364: 2027-2045.

Thompson, R.C, C.J Moore, F.S vom Saal and S.H Swan. 2009. Plastics, The Environment and Human Health: Current Consensus and Future Trends. Philos. Trans. R. Soc. Lond. B 364: 2153-2166. http://dx.doi.org/10.1098/ rstb.2009.0053.

[UNEP] United Nations Environment Programme. 2011. UNEP Year Book 2011: Emerging Issues in Our Global Environment. Nairobi (KE): UNEP. 79 hal.

Van Cauwenberghe, L. and C.R. Janssen.
2014. Microplastics in Bivalves Cultured for Human Consumption. Env. Poll. 193: 65-70.

Van Franeker, J.A., C. Blaize, J. Danielsen, K. Fairclough, J. Gollan, N. Guse, P.L. Hansen, M. Heubeck, J.K. Jensen, G. Le Guillou, B. Olsen, K.O. Olsen, J. Pedersen, E.W.M Stienen and D.M Turner. 2011. Monitoring Plastic Ingestion By The Northern Fulmar Fulmarus Glacialis in The North Sea. Env. Poll. 159: 2609-2615.

von Moos, N., P. Burkhardt-Holm and A. Koehler. 2012. Uptake and Effects of Microplastics on Cells and Tissues of The Blue Mussel Mytilus edulis L. After Experimental Exposure. Environmental Science and Technology. 46: 11327-11335.

Wegner, A., E. Besseling, E. M. Foekema, P. Kamermans, and A. A. Koelmans. 2012. Efects Of Nanopolystyrene on The Feeding Behavior of The Blue Mussel (Mytilus edulis L.). Environ. Toxicol. Chem. 31: 2490-2497.

Wright, S.L., R.C. Thompson and T. S. Galloway. 2013. The Physical Impact of Microplastics On Marine Organisms: A Review. Env. Poll. 178: 483-492.

Zarfl, C. and M. Matthies. 2010. Are Marine Plastic Particles Transport Vectors for Organic Pollutants to The Arctic? Mar. Poll. Bull. 60 (10): 1810-1814. 